\title{
Amazonia atlantiicola sp. nov. (Ascomycetes, Meliolales) from Malabar Wildlife Sanctuary in Kerala State, India
}

\author{
Lini KM $\mathbf{M}^{1}$, Neeta $\mathrm{NN}^{1}$ and Swapna $\mathrm{S}^{1}$ \\ ${ }^{1}$ Post Graduate \& Research Dept. of Botany, Mar Thoma College, Thiruvalla - 689 103, Pathanamthitta, Kerala, India.
}

Lini KM, Neeta NN, Swapna S 2017 - Amazonia atlantiicola sp. nov. (Ascomycetes, Meliolales) from Malabar Wildlife Sanctuary in Kerala State, India. Studies in Fungi 2(1), 14-16, Doi $10.5943 / \mathrm{sif} / 2 / 1 / 2$

\begin{abstract}
A new species, Amazonia atlantiicola, infecting leaves of Atlantia sp. (Rutaceae), was collected from Malabar Wildlife Sanctuary of Kozhikode district. It is introduced, described and illustrated in this paper.
\end{abstract}

Key words - Atlantia - black mildew - new species

\section{Introduction}

The family Meliolaceae is treated under the orderMeliolales. The members belonging to this family often regarded as minor plant pathogens which forming black colonies on the leaves surface of host plants. The genus Amazonia is accepted in the family Meliolaceae (Hansford, 1961, Hosagoudar 1996, 2008, Hosagoudar \& Agarwal 2008, Hongsanan et al. 2015). During a survey of the foliicolous fungi in Malabar Wildlife Sanctuary in Western Ghats region of Kerala State, India, a black mildew fungus was collected on the leaves of Atlantia sp. (Rutaceae). Microscopic examinations of the infected plants revealed that it is hitherto undescribed species of the genus Amazonia Theiss, and hence, this note.

\section{Materials and Methods}

Infected plant parts were selected in the field, field notes were made regarding their nature of colonies, nature of infection and the collection locality. For each collection, a separate field number was given. In the field, each infected plant was collected separately in polythene bags along with the host twig (preferably with the reproductive parts to facilitate the identity of the corresponding host). These infected plant parts were pressed neatly and dried in-between blotting papers. After ensuring their dryness, they were used for microscopic study. Scrapes were taken directly from the infected host and mounted in $10 \% \mathrm{KOH}$ solution. After 30 min, $\mathrm{KOH}$ was replaced by Lactophenol. Both the mountants work well as clearing agents and made the septa visible for taking measurements. To study the entire colony in its natural condition, a drop of high quality natural colored or well transparent nail polish was applied to the selected colonies and carefully thinned with the help of a fine brush without disturbing the colonies. Colonies with hyper parasites showing a woolly nature were avoided. The treated colonies along with their host plants were kept in dust free chamber for half an hour. 


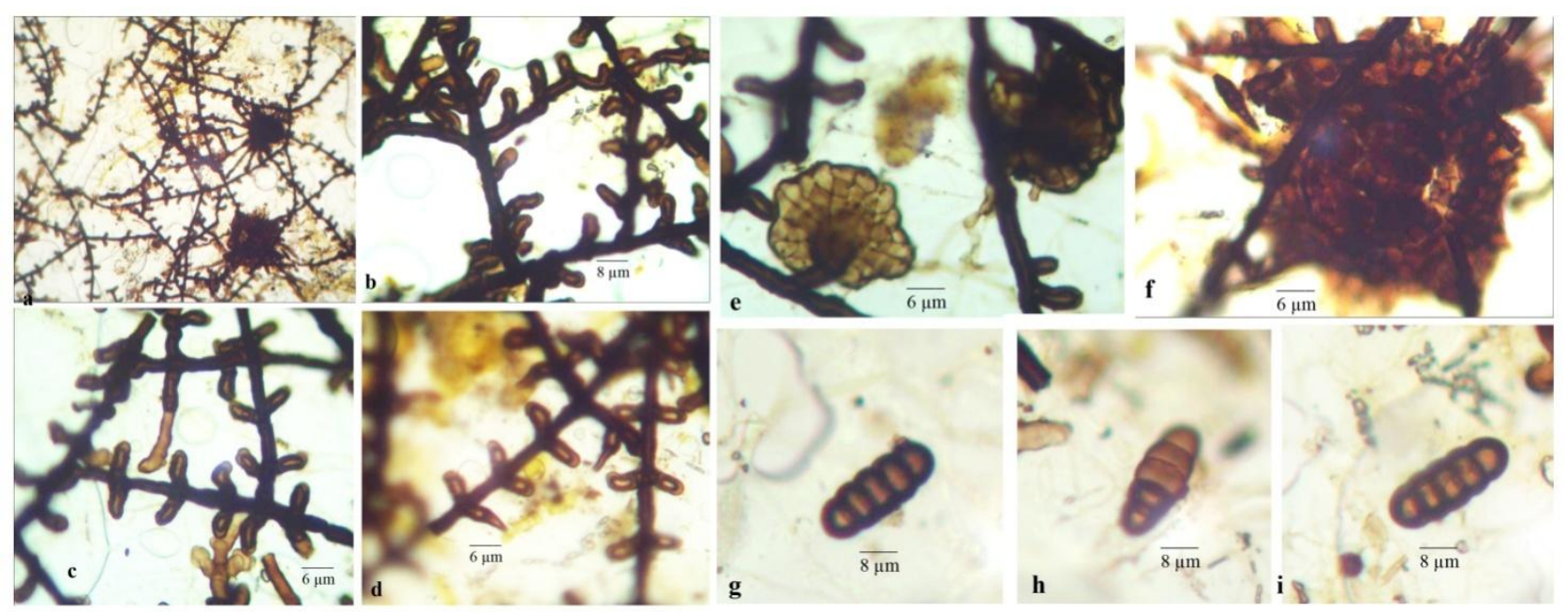

Fig. 1 - Amazonia atlantiicola (holotype). a Colony with perithecia. b,c Appressoriate mycelium, $\mathrm{d}$ Appressoriate mycelia with phialides. e Developing perethecia. f Mature dehisced perithecium. gi Ascospores.

When the nail polish on the colonies dried fully, a thin, colorless or slightly apple rose colored (depending upon the colour tint in the nail polish) film or flip was formed with the colonies firmly embedded in it. In case of soft host parts, the flip was lifted off with a slight pressure on the opposite side of the leaves and just below the colonies. In case of hard host parts, the flip was eased off with the help of a razor or scalpel. A drop of DPX was spread on a clean slide and the flip was spread properly on it. One or two more drops of DPX were added additionally on the flip and a clean cover glass was placed over it. By gently pressuring on the cover glass, excessive amount of DPX was removed after drying. Care was taken to avoid air bubbles.

These slides were labeled and placed in a dust free chamber for one to two days for drying. These permanent slides were then used for further studies. For innate fungi, sections were made and stained in cotton blue. After the study of each collection, part of the material was retained in the regional herbarium, Mar Thoma College Herbarium, Thiruvalla (MTCHT).

Amazonia atlantiicola Lini K. Mathew \& Neeta N. Nair sp. nov.

Fig. 1

Index Fungorum Number: 552462; Facesoffungi number: FoF 03249

Etymology: Name after the host

Holotype: MTCHT 110

Colonies amphigenous, mostly epiphyllous, subdense, velvety, up to $2 \mathrm{~mm}$ in diameter, confluent. Hyphae straight to substraight, branching alternate to opposite at acute to wide angles, loosely to closely reticulate, cells $14.4-38.4 \times 4.8-6 \mu \mathrm{m}$. Appressoria alternate to unilateral to opposite, straight to curved, antrorse to subantrorse to retrorse, 9.6-12 $\mu \mathrm{m}$ long; stalk cells cylindrical to cuneate, 2.4-3 $\mu \mathrm{m}$ long; head cells ovate to globose, cylindrical to entire, curved, 7.2-9.6 x 4.8-7.2 $\mu \mathrm{m}$. Phialides mixed with appressoria, alternate to opposite, ampulliform, 9.6$14.4 \times 2.4-4.8 \mu \mathrm{m}$. Perithecia scattered, flattened-globose in radiating hyphae, up to $180 \mu \mathrm{m}$ in diameter; ascospores cylindrical, 4-septate, constricted at the septa, 19.2-21.6 x 9.2-12 $\mu \mathrm{m}$.

Material examined - India, Kerala, Kozhikode,Malabar Wildlife Sanctuary,near Peruvannamuzhi Dam, on leaves of Atlantia sp.(Rutaceae), 23, February, 2013,Lini K. Mathew, (MTCHT 110, holotype).

\section{Discussion}

Amazonia acronychiae Hosag. and A. melicopecola Hosag. \& Abraham is the only known species in the genus Amazonia on the members of the family Rutaceae (Hosagoudar \& Goos 1989, Hosagoudar \& Abraham 1998). The present species differs from Amazonia melicopecola and A. 
acronichiae in having both alternate and opposite appressoria. Based on morphological dissimilarities and host specificity it can be accommodated in new species.

\section{Acknowledgement}

We are grateful to K. Jacob, Principal and Dr. Elizabeth T. Mangatt, HOD Botany, Mar Thoma College; Registrar, Mahatma Gandhi University Kottayamfor the facilities.

\section{References}

Hansford CG.1961 - The Meliolineae. A Monograph. Sydowia Beih. 2, 1-806.

Hongsanan S, Tian Q, Peršoh D. 2015 - Meliolales, Fungal Diversity 74, 91.

Hosagoudar VB. 1996 - Meliolales of India. Botanical Survey of India, Calcutta, pp.363.

Hosagoudar VB, Abraham TK. 1998 - Someinteresting meliolaceous fungi from Kerala, India. Journal of mycopathological Research 36, 97.

Hosagoudar VB. 2008 - Meliolales of India. Vol. II. Botanical Survey of India, Calcutta, pp. 390.

Hosagoudar VB, Goos RD. 1989 - Meliolaceous fungi from the state of Kerala, India I. Mycotaxon $36,221-247$.

Hosagoudar VB, Agarwal DK. 2008 - Taxonomic studies of Meliolales. Identification Manual. International Book Distributors, Dehra Dun, pp. 263. 